\begin{tabular}{|l|l|l||}
\hline \multicolumn{2}{|c|}{ PublisherInfo } \\
\hline \hline PublisherName & $:$ & BioMed Central \\
\hline \hline PublisherLocation & $:$ & London \\
\hline \hline PublisherImprintName & $:$ & BioMed Central \\
\hline \hline
\end{tabular}

\title{
BNIP3: a new cell death pathway regulating necrosis?
}

\begin{tabular}{|l|l|l||}
\hline \multicolumn{2}{|c|}{ ArticleInfo } \\
\hline \hline ArticleID & $:$ & 157 \\
\hline \hline ArticleDOI & $:$ & $10.1186 /$ ar-2000-66839 \\
\hline \hline ArticleCitationID & $:$ & 66839 \\
\hline \hline ArticleSequenceNumber & $:$ & 114 \\
\hline \hline ArticleCategory & $:$ & Paper Report \\
\hline \hline ArticleFirstPage & $:$ & 1 \\
\hline \hline ArticleLastPage & $:$ & 3 \\
\hline \hline & & RegistrationDate : 2000-9-12 \\
\hline ArticleHistory & $:$ & OnlineDate \\
\hline \hline ArticleCopyright & $:$ & Current Science Ltd2000-9-12 \\
\hline \hline ArticleGrants & $:$ & \\
\hline \hline ArticleContext & $:$ & 130753311 \\
\hline \hline
\end{tabular}


Affl Center of Experimental Rheumatology, Zurich, Switzerland

\section{Keywords}

BNIP3, mitochondria, necrosis

\section{Context}

Several apoptotic pathways involve mitochondria. Caspase activation, a major event in the induction of cell death, is regulated by mitochondria. Apoptosis inducing factor (AIF) is a mitochondria associated protein involved in DNA fragmentation when translocated to the nucleus. Permeability transition (PT) pore opening occurs in both apoptosis and necrosis. Necrosis is distinguished by an early loss of plasma membrane integrity, which is preserved during apoptosis. To identify which pathway resulting in cell death is activated by the mitochondria associated protein BNIP3.

\section{Significant findings}

In contrast to most of the cells transduced with tBID, cytochrome c release prior to apoptosis was not observed in BNIP3 transfected cells. In addition, BNIP3-induced cell death was unaffected by caspase inhibitors, whereas they inhibited apoptosis of tBID or caspase 9/Apaf 1 transfectants. BNIP3 overexpression in mutant cells which were not expressing Apaf 1, caspase 9 or caspase 3 reversed their resistance to cell apoptosis. No AIF translocation to the nucleus was observed. However, DNA fragmentation was noted. In contrast to cells transfected with tBID, BAX, or caspase 9/Apaf 1, plasma membrane permeability increased very early post-transfection, without increase in annexin V. Many rounded mitochondria with destroyed internal cisternae, extensive cytoplasmic vacuoles, and autophagosomes were observed. BNIP3 was almost as efficient as tBID at suppressing ??m, ROS generation, and inducing cell death. All these effects were reversed by treatment of BNIP3 transfectants with cyclosporin A, bongkrekic acid, or when Bcl-2 and Bcl-XL were overexpressed.

\section{Comments}


Until now, differences between necrosis and programmed cell death (apoptosis) were wellestablished. Vande Velde and his colleagues have, in this paper, studied the mechanisms of BNIP3 induced cell death. BNIP3, a mitochondrial associated protein, induces cell death independently of Apaf-1, cytochrome c release, caspase activation, or translocation of apoptosis-inducing factor. In addition, cells exhibit early plasma membrane permeability, and cytoplasmic vacuolation, which are consistent with necrosis. However, mitochondrial dysfunctions and DNA fragmentation, which reflect features more typical of apoptotic cell death, are also observed. BNIP3-induced cell death can be partly reversed by cyclosporin A, bongkrekic acid, or Bcl-2 or BclXL overexpression. Therefore, BNIP3 induces a novel form of necrotic cell death, as a consequence of mitochondrial permeability transition pore opening.

\section{Methods}

Overexpression of BNIP3, tBID, or capase 9 plus Apaf 1 after transfer of the respective genes into different cell lines resulted in cell death. Cytochrome $\mathrm{c}$ release was evaluated by immunofluorescence and western blot. Contribution of Apaf-1, caspase 9, or caspase 3 in BNIP3-induced cell death was studied in cells deficient in these genes. The caspase inhibitors Ac-zVAD-fmk and AC-zDEVD-fmk were used to determine the role of caspases in BNIP3-induced cell death. Immunofluorescence and immunoblotting were used to check AIF translocation to the nucleus. DNA fragmentation was shown using TUNEL and agarose gel electrophoresis. Plasma membrane integrity and annexin V binding were also studied. Evaluation of PT pore opening, loss of membrane potential of mitochondria (??m) and radical oxygen species (ROS) production were used to measure the protective effect of cyclosporin A, bongkrekic acid, overexpression of Ncl-2 and Bcl-X .

\section{References}

1. Vande Velde C, Ciseau J, Dubik D, Alimonti J, Brown T, Israels S, Hakem R, Greenberg AH: BNIP3 and genetic control of necrosis-like cell death through the mitochondrial permeability transition pore. Am J Pathol . 2000, 156: 1887-1900.

This PDF file was created after publication. 